\title{
SPREMEMBE VOLILNIH ENOT ZA IZVEDBO VOLITEV V DRŽAVNI ZBOR RS
}

Izvirni znanstveni članek

COBISS 1.01

DOI: $10.4312 /$ dela.53.45-69

\section{Izvleček}

Leta 2018 sprejeta odločba Ustavnega sodišča o neustavnosti trenutne ureditve volilnih okrajev je znova oživila razpravo o reformi državnozborskega volilnega sistema. $\mathrm{V}$ središču razprave je vprašanje preoblikovanja oziroma odprave volilnih okrajev. Drugi pomembni prostorski element volilnega sistema - ureditev volilnih enot - pa ni deležen večje pozornosti, saj ni bila predmet ustavne presoje. $V$ članku želimo preveriti, v kolikšni meri obstoječa ureditev še izpolnjuje zakonska merila. V nadaljevanju so predstavljeni trije alternativni predlogi ureditve volilnih enot, njihove ključne značilnosti ter glavne prednosti in pomanjkljivosti.

Ključne besede: volilna geografija, volitve, volilni sistemi, volilne enote, Slovenija, Državni zbor Republike Slovenije

\section{CHANGES OF ELECTORAL UNITS FOR THE CONDUCT OF ELECTIONS TO THE NATIONAL ASSEMBLY OF THE REPUBLIC OF SLOVENIA}

\section{Abstract}

The decision of the Constitutional Court, adopted in 2018, on the unconstitutionality of the current arrangement of electoral districts (volilni okraji) has revived the debate on a reform of the National Assembly electoral system. The main question of the reform is whether the electoral counties should be newly divided or abandoned. Not much

\footnotetext{
* Oddelek za geografijo, Filozofska fakulteta Univerze v Ljubljani, Aškerčeva 2, SI-1000 Ljubljana e-pošta: bostjan.rogelj@ff.uni-lj.si
} 
attention is paid to the second important spatial element of the electoral system - the arrangement of the electoral units (volilne enote) - since it was not the subject of a constitutional review. The study examined to what extent the current arrangement of the electoral units meets the legal criteria. Finally, three alternative proposals for the arrangement of the electoral units are presented. The key features of the proposals and their main advantages and disadvantages are presented as well.

Key words: electoral geography, elections, electoral systems, electoral units, Slovenia, National Assembly of the Republic of Slovenia

\section{UVOD}

Ureditev volilnih enot in volilnih okrajev v volilnem sistemu za volitve poslancev v Državni zbor Republike Slovenije (v nadaljevanju državnozborski volilni sistem) je vse od uveljavitve deležna številnih kritik (glej Gaber, 1996; Pogorelec, 1998; 2000; Ribičič, 1999; Rogelj, 2011; 2012). O primernosti ureditve je večkrat presojalo tudi Ustavno sodišče RS. V odločbi, izdani novembra 2018, je presodilo, da je 4. člen Zakona o določitvi volilnih enot za volitve poslancev v Državni zbor (v nadaljevanju ZDVEDZ) v neskladju z Ustavo (Ustavno sodišče RS, 2018). Po mnenju ustavnih sodnikov volilni okraji ne ustrezajo več nobenemu merilu iz 20. člena Zakona o volitvah v Državni zbor (v nadaljevanju ZVDZ). Problematične so tako velike razlike v velikosti volilnih okrajev kot dejstvo, da niso spoštovane niti meje sedanjih občin niti merilo geografske zaokroženosti. Ustavno sodišče je naložilo Državnemu zboru, da v dveh letih odpravi ugotovljeno protiustavnost (Ustavno sodišče, 2018).

Na pobudo predsednika republike so marca 2019 stekla pogajanja o morebitnih spremembah volilne zakonodaje. V okviru pogajanj sta se oblikovala dva predloga odprave neustavnega stanja (RTVSLO, 2019). Prvi predvideva temeljitejšo spremembo volilnega sistema $\mathrm{z}$ uvedbo relativnega prednostnega glasu in odpravo volilnih okrajev. Drugi predvideva le preoblikovanje meja volilnih okrajev. Prvi zahteva spremembo ZVDZ, za kar je potrebna dvotretjinska večina v Državnem zboru. Drugi zahteva le spremembo ZDVEDZ, za kar zadostuje že navadna večina.

Oba predloga sprememb volilne zakonodaje ne predvidevata bistvenih sprememb $\mathrm{v}$ ureditvi volilnih enot, ki so drugi pomemben prostorski element državnozborskega volilnega sistema. To ni presenetljivo, saj le-ta ni bila predmet presoje Ustavnega sodišča. Na splošno velja, da je bila ureditev volilnih enot $\mathrm{v}$ preteklosti deležna bistveno manj kritik kot ureditev volilnih okrajev. Z izjemo predloga dvokrožnega večinskega volilnega sistema nobena predlagana reforma državnozborskega volilnega sistema ni predvidevala korenitejših sprememb ureditve volilnih enot. 
V članku želimo preveriti, ali je obstoječa ureditev volilnih enot res neproblematična. Članek je sestavljen iz petih delov. Uvodnemu delu sledi teoretično-metodološki del, v katerem je predstavljena vloga volilnih enot v volilnih sistemih. Tretji del je posvečen analizi obstoječe ureditve, predvsem ali ta še izpolnjuje zakonsko določena merila. $\mathrm{V}$ četrtem delu so predstavljeni trije alternativni predlogi ureditve volilnih enot. V sklepu je podana ocena smiselnosti reforme obstoječe ureditve volilnih enot $\mathrm{v}$ okviru obeh predlogov sprememb volilne zakonodaje.

\section{VLOGA VOLILNIH ENOT V VOLILNIH SISTEMIH}

Volilne enote so prostorske enote, $\mathrm{v}$ katerih se zbirajo volilni glasovi in delijo mandati $\mathrm{v}$ predstavniškem telesu. Skupaj z volilno formulo, strukturo glasovnice in volilnim pragom so ključni element volilnega sistema. Delitev ozemlja, na katerem potekajo volitve na volilne enote, je nujno potrebna le v volilnih sistemih, temelječih na večinski volilni formuli. V volilne sisteme, zasnovane na proporcionalni formuli, je navadno vključena zaradi želje po večji geografski reprezentativnosti (s terminom geografska reprezentativnost označujemo enakomerno prostorsko porazdelitev mandatov po ozemlju, na katerem potekajo volitve), zagotavljanju tesnejše povezanosti med poslanci in volivci ter lažje organizacije volitev (Rogelj, 2012).

$\mathrm{Z}$ oblikovanjem volilnih enot se mandati prostorsko razpršijo po celotnem območju volitev, s čimer se posameznim območjem zagotovi zastopanost v predstavniškem telesu. Če celotno ozemlje tvori ena ali manjše število zelo velikih volilnih enot, obstaja nevarnost, da bo večina izvoljenih predstavnikov prišla iz političnih, gospodarskih in prebivalstvenih središč, politično in gospodarsko manj pomembna ter redkeje poseljena območja pa v predstavniškem telesu ne bodo zastopana (Farrell, 2001). Načeloma velja, da se $\mathrm{z}$ manjšanjem velikosti volilnih enot (s terminom velikost volilne enote označujemo število mandatov, ki se volijo v volilni enoti) povečuje geografska reprezentativnost predstavniškega telesa.

Zagotavljanje tesnejše povezanosti med poslanci in volivci je drugi pomemben razlog za razdelitev ozemlja na volilne enote. $V$ manjših enotah ima volivec boljši pregled nad kandidati, kar mu omogoča, da ne glasuje le za liste, temveč tudi za posamezne kandidate (v obliki preferenčnega glasovanja ali panaširanja ${ }^{1}$ ). Tako manjše volilne enote zagotavljajo višjo stopnjo personifikacije volilnega sistema (termin personifikacija označuje

1 Preferenčno glasovanje oz. prednostni glas omogoča volivcu, da znotraj liste/stranke glasuje za posameznega kandidata. Glasovanje za kandidata je lahko obvezno ali pa opcijsko. V prvem primeru govorimo o absolutnem, v drugem o relativnem preferenčnem glasovanju. V primeru uporabe relativnega preferenčnega glasovanja se navadno določi prag (število oziroma delež dobljenih glasov znotraj stranke/liste), ki ga mora kandidat doseči, da se preferenčni glasovi upoštevajo pri končni delitvi mandatov (Krašovec, 2007; ACE Project, 2020b). Panaširanje je oblika preferenčnega glasovanja, pri katerem ima volivec več glasov, pri čemer lahko vse glasove podeli kandidatom ene strankarske liste ali pa glasove razdeli med kandidate različnih strankarskih list (ACE Project, 2020b). 
vpliv volivca na izbiro kandidata). $\mathrm{V}$ velikih volilnih enotah je glasovanje o kandidatih nepregledno ter tehnično in organizacijsko bolj zapleteno. Zato je tudi redkeje omogočeno, kadar pa je, manj vpliva na volilne rezultate (Krašovec, 2007). Manjše volilne enote poleg tega vzpostavljajo tesnejše vezi med poslanci in volivci. Poslanci čutijo večjo odgovornost do volivcev, zato pogosto delujejo kot zastopniki določenega območja oz. regije. Podobno velja za volivce. Manjše volilne enote dajejo volivcem občutek tesnejše povezanosti in lažje dostopnosti poslancev (glej Strøm idr., 2006).

Velikost volilnih enot je eden ključnih dejavnikov, ki vplivajo na stopnjo proporcionalnosti delitve mandatov. $Z$ vidika zagotavljanja čim višje stopnje proporcionalnosti je oblikovanje volilnih enot celo nezaželeno. Velikost volilnih enot ustvarja t. i. dejanski volilni prag (ang. effective threshold; $\mathrm{v}$ slovenščini se uporabljata tudi izraza naravni oziroma neformalni volilni prag). Le-ta je najvišji v enomandatnih oz. uninominalnih volilnih enotah, $\mathrm{z}$ naraščanjem velikosti volilnih enot pa se znižuje, kar povečuje proporcionalnost delitve mandatov. Najvišjo stopnjo proporcionalnosti dosežemo, če je celotno ozemlje, na katerem potekajo volitve, ena volilna enota (Lijphart, 1994).

$\mathrm{V}$ volilnih sistemih $\mathrm{z}$ večnivojsko delitvijo mandatov (sem spada tudi državnozborski volilni sistem) velikost volilne enote pomembno vpliva na delež mandatov, ki se jih razdeli na nižjih oziroma višjih ravneh delitve mandatov. $V$ manjših volilnih enotah se zaradi visokega dejanskega volilnega praga razdeli bistveno manj mandatov kot $\mathrm{v}$ večjih. Posledično se večji delež mandatov razdeli na višjih ravneh delitve mandatov (navadno na nacionalni ravni). V preglednici 1 je prikazana višina dejanskega volilnega praga pri uporabi Droopovega količnika za delitev mandatov v volilnih enotah (sistem, ki je uporabljen pri državnozborskih volitvah). Medtem ko je treba za pridobitev mandata v 5-mandatnih volilnih enotah zbrati 16,7 \% glasov, v 10-mandatnih enotah zadostuje že $9,1 \%$ glasov.

Preglednica 1: Višine dejanskega volilnega praga pri uporabi Droopovega količnika za delitev mandatov $v$ volilnih enotah.

\begin{tabular}{|c|c|c|c|c|c|c|c|}
\hline $\begin{array}{c}\text { Velikost } \\
\text { volilne } \\
\text { enote }\end{array}$ & $\begin{array}{c}\text { Dejanski } \\
\text { volilni } \\
\text { prag }\end{array}$ & $\begin{array}{c}\text { Velikost } \\
\text { volilne } \\
\text { enote }\end{array}$ & $\begin{array}{c}\text { Dejanski } \\
\text { volilni } \\
\text { prag }\end{array}$ & $\begin{array}{c}\text { Velikost } \\
\text { volilne } \\
\text { enote }\end{array}$ & $\begin{array}{c}\text { Dejanski } \\
\text { volilni } \\
\text { prag }\end{array}$ & $\begin{array}{c}\text { Velikost } \\
\text { volilne } \\
\text { enote }\end{array}$ & $\begin{array}{c}\text { Dejanski } \\
\text { volilni } \\
\text { prag }\end{array}$ \\
\hline 1 & 50,0 & 6 & 14,3 & 11 & 8,3 & 16 & 5,9 \\
\hline 2 & 33,3 & 7 & 12,5 & 12 & 7,7 & 17 & 5,6 \\
\hline 3 & 25,0 & 8 & 11,1 & 13 & 7,1 & 18 & 5,3 \\
\hline 4 & 20,0 & 9 & 10,0 & 14 & 6,7 & 19 & 5,0 \\
\hline 5 & 16,7 & 10 & 9,1 & 15 & 6,3 & 20 & 4,8 \\
\hline
\end{tabular}

Volilne enote pomembno vplivajo tudi na naravo strankarskega tekmovanja. Dejanski volilni prag lahko močno zaostri pogoje za pridobitev mandata (Monroe, Rose, 2002). $Z$ vidika enakopravnosti in nepristranskosti volilne tekme je najbolje, da je 
ozemlje razdeljeno na enako velike volilne enote. $\mathrm{V}$ nasprotnem primeru se lahko zgodi, da imajo posamezne stranke zaradi specifične prostorske porazdelitve volilne podpore določeno prednost pri pridobivanju mandatov.

Volilne enote pomembno vplivajo tudi na spoštovanje načela enake volilne pravice. Skladno z njim mora imeti glas vsakega volivca enak vpliv na volilne rezultate. Volilne enote morajo biti oblikovane tako, da $\mathrm{v}$ vseh en mandat voli približno enako število volivcev. V svetu ni enotnega standarda glede dovoljenega odstopanja. V ZDA so na ravni zveznih držav razlike v povprečju manjše od 0,6 \% (Webster, 2013). Vrhovno sodišče je v odločbi Karcher proti Daggett leta 1983 odločilo, da so tudi razlike, manjše od $1 \%$, neustavne, če je mogoče oblikovati ureditev z manjšimi odstopanji (Handley in sod., 2006). Beneška komisija priporoča največ desetodstotno, v res izjemnih primerih pa petnajstodstotno odstopanje v velikosti volilnih enot (Beneška komisija, 2002; 2013). Nekatere države dovoljujejo tudi bistveno večja odstopanja. Volilna formula pri tem ne igra bistvene vloge. V Veliki Britaniji, kjer je volilni sistem zasnovan po večinski volilni formuli, je največja volilna enota petkrat večja od najmanjše (na volitvah leta 2019 je volilna enota Na h-Eileanan an Iar štela 21.106 volivcev, volilna enota Otok Wight pa 113.021 volivcev (Uberoi in sod., 2020)). V Severni Makedoniji, ki ima volilni sistem zasnovan po proporcionalni volilni formuli, pa je dovoljeno le 5-odstotno odstopanje (IFES, 2019).

Večja odstopanja se navadno dovoljujejo, kadar se prostorski obseg volilnih enot prilagaja obstoječi upravno-administrativni delitvi ozemlja (na primer mejam regij, pokrajin, zveznih dežel, provinc ...). V tem primeru je prostorski obseg volilnih enot določen vnaprej, zakonodajalec pa mora določiti sistem, po katerem se mandati razdelijo po posameznih volilnih enotah. Tako ima vsaka upravno-administrativna enota zagotovljeno točno določeno število predstavnikov v predstavniškem telesu (Rogelj, 2012).

Manjša odstopanja so značilna za sisteme, pri katerih je velikost volilnih enot fiksno določena, njihov prostorski obseg pa se temu prilagaja. V tem primeru prostorski obseg volilnih enot le delno sledi upravno-administrativni delitvi ozemlja, navadno so večje enote razdeljene na več volilnih enot, manjše pa združene v eno volilno enoto. Katera merila morajo oblikovalci upoštevati pri določitvi prostorskega obsega volilnih enot, po navadi določa zakonodaja. Poleg števila prebivalcev/volivcev se najpogosteje uporabljajo različna geografska merila (geografska dostopnost, homogenost, funkcijska povezanost ...) (Handley in sod., 2006). Zakonodaja navadno določa tudi, kdaj je treba volilne enote preoblikovati in kdo vodi oziroma nadzira celoten postopek.

\section{VOLILNE ENOTE V DRŽAVNOZBORSKEM VOLILNEM SISTEMU}

Ureditev volilnih enot pri volitvah v Državni zbor RS urejata dva zakona. ZVDZ (2017) določa njihovo število, velikost in merila za oblikovanje. Dvajseti člen zakona določa, da se za potrebe volitev poslancev državnega zbora oblikuje osem volilnih 
enot, da se v vsaki volilni enoti voli enajst poslancev ter da se volilne enote oblikujejo $v$ skladu z načelom, da se en poslanec voli na približno enako število prebivalcev. Omenjeni člen hkrati določa, da je pri oblikovanju volilnih enot in volilnih okrajev treba upoštevati geografsko zaokroženost ter skupne kulturne in druge značilnosti teh. Prostorski obseg posameznih volilnih enot določa ZDVEDZ (2005). Prostorski obseg je določen na podlagi upravno-administrativne delitve Slovenije na občine iz leta 1992.

Ureditev volilnih enot $\mathrm{v}$ državnozborskem volilnem sistemu je zasnovana na treh merilih, od katerih je le eno natančno specificirano. Prvo merilo je velikost volilnih enot. Zakon jasno določa, da mora biti država razdeljena na osem enako velikih volilnih enot (v vsaki se voli enajst mandatov). Enaka volilna pravica je drugo merilo. En mandat naj bi volilo približno enako število prebivalcev, pri čemer pa ni nikjer določeno, kakšna odstopanja so še dovoljena. Še bolj nedorečeno je tretje merilo geografska zaokroženost in skupne kulturne in druge značilnosti.

Volilne enote so bile oblikovane leta 1992. Od takrat so nastale pomembne spremembe $\mathrm{v}$ prostorski razporeditvi prebivalcev, upravno-administrativni ureditvi in prostorskem razvoju Slovenije. Posledično se postavlja vprašanje, v kolikšni meri obstoječa ureditev volilnih enot še izpolnjuje zakonsko določena merila.

Ali ureditev volilnih enot še zagotavlja spoštovanje načela enake volilne pravice? $\mathrm{Na}$ to vprašanje je težko dati jasen odgovor. Zakonodaja ne kvantificira termina "približno" v drugem odstavku 20. člena ZVDZ, ki pravi: »Volilne enote se oblikujejo v skladu z načelom, da se en poslanec voli na približno enako število prebivalcev.« Že prej smo omenili, da glede višine dovoljenih odstopanj ni enotnih mednarodnih standardov. Hrvaška in Severna Makedonija, ki imata podobno ureditev volilnih enot kot Slovenija, dovoljujeta največ 5-odstotna odstopanja (IFES, 2019; Zakon o izborima zastupnika ..., 2019). Podobno stališče ima Ustavno sodišče RS. Le-to je v več odločbah presodilo, da so do 5-odstotni odkloni od velikosti idealne volilne enote pravno sprejemljivi in da zaradi njih ni kršeno načelo enake volilne pravice (Ustavno sodišče RS, 1992; 2003).

Danes največja volilna enota (VE 4) za $6,1 \%$ odstopa od povprečja, najmanjša pa za 4,9 \% (glej preglednico 2 in sliko 2). Zgodovinsko gledano trenutna odstopanja niso problematična, saj so podobna tistim iz leta 1992 (glej preglednico 2). Bolj problematičen je trend spreminjanja števila volivcev. Medtem ko so se do leta 2011 razlike postopoma zmanjševale (glej Rogelj, 2012), se v zadnjem času znova povečujejo. Z vidika zagotavljanja načela enake volilne pravice sta najbolj problematična hitra rast prebivalstva $\mathrm{v}$ dveh osrednjeslovenskih volilnih enotah (VE 3 in VE 4) in nenehno upadanje prebivalstva $\mathrm{v}$ treh vzhodnoslovenskih volilnih enotah (VE 5, VE 7 in VE 8). Ob nadaljevanju trenutnih trendov lahko pričakujemo, da bo do leta 2025 razlika med največjo in najmanjšo volilno enoto približno 15-odstotna.

Še teže je dati jasen odgovor na vprašanji, v kolikšni meri so obstoječe volilne enote geografsko zaokrožene in v kolikšni meri ureditev volilnih enot upošteva skupne kulturne in druge značilnosti. Usklajenost meja volilnih enot z mejami občin je ena od mogočih ocen geografske zaokroženosti volilnih enot. Občine in krajevne skupnosti 
Preglednica 2: Število volivcev po volilnih enotah v letih 1992 in 2019.

\begin{tabular}{|l|l|l|l|l|l|}
\hline $\begin{array}{l}\text { Volilna } \\
\text { enota }\end{array}$ & Sedež volilne enote & $\begin{array}{l}\text { Število } \\
\text { volivcev } \\
1992\end{array}$ & $\begin{array}{l}\text { Odstopanje } \\
\text { od povprečja } \\
\text { (v \%) 1992 }\end{array}$ & $\begin{array}{l}\text { Število } \\
\text { volivcev } \\
2019\end{array}$ & $\begin{array}{l}\text { Odstopanje } \\
\text { od povprečja } \\
\text { (v \%) 2019 }\end{array}$ \\
\hline VE 1 & Kranj & 176.319 & $-5,4$ & 209.353 & $-1,7$ \\
\hline VE 2 & Postojna & 181.077 & $-2,9$ & 209.836 & $-1,5$ \\
\hline VE 3 & Ljubljana - Center & 181.955 & $-2,4$ & 218.659 & $+2,7$ \\
\hline VE 4 & Ljubljana - Bežigrad & 189.635 & $+1,7$ & 225.951 & $+6,1$ \\
\hline VE 5 & Celje & 191.514 & $+2,7$ & 214.138 & $+0,6$ \\
\hline VE 6 & Novo mesto & 180.415 & $-3,2$ & 202.434 & $-4,9$ \\
\hline VE 7 & Maribor & 197.539 & $+6,0$ & 211.726 & $-0,6$ \\
\hline VE 8 & Ptuj & 192.920 & $+3,5$ & 211.367 & $-0,7$ \\
\hline Povprečno št. volivcev v VE & 186.422 & - & 212.933 & - \\
\hline
\end{tabular}

Vir podatkov: DVK, 2019; MNZ, 2019.

Slika 1: Odstopanje števila volivcev $v$ volilni enoti od povprečnega števila volivcev $v$ obdobju 1992-2019.

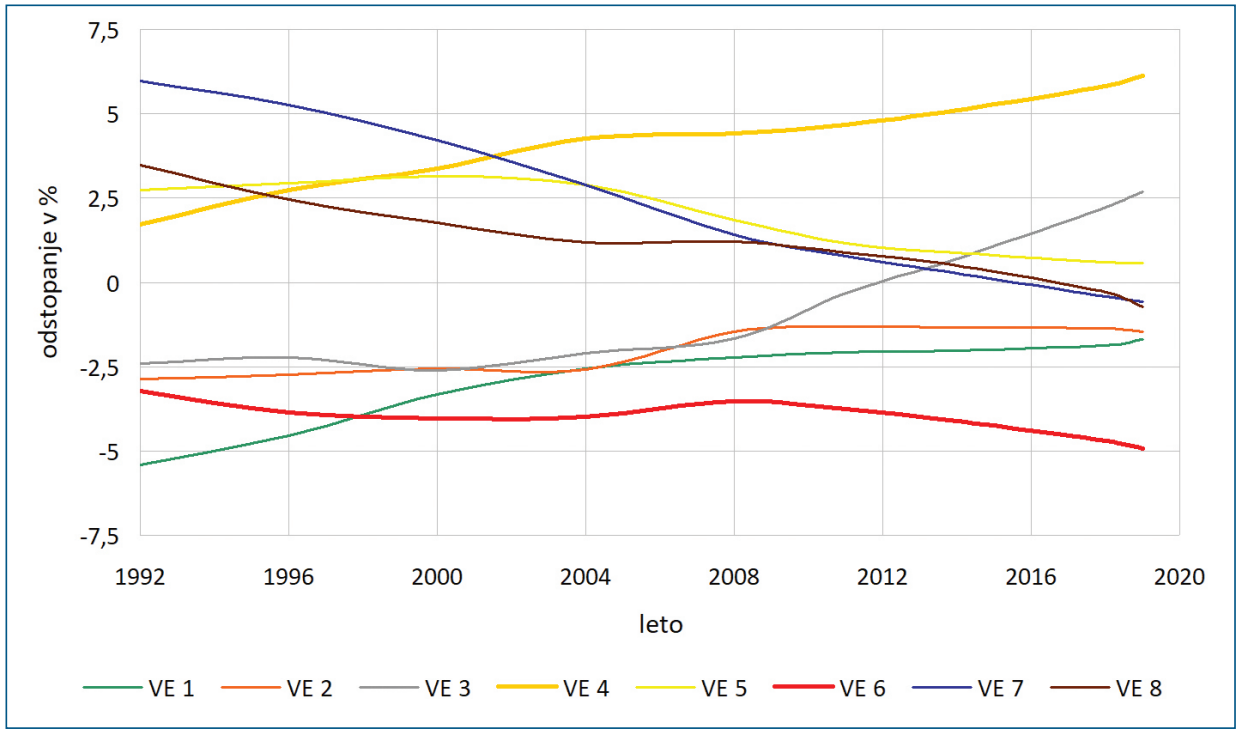

Vir podatkov: DVK, 2019; MNZ, 2019. 
so bile leta 1992 uporabljene kot osnovni gradnik pri oblikovanju volilnih enot in volilnih okrajev. S poznejšimi reformami lokalne samouprave se je upravno-administrativna razdelitev Slovenije močno spremenila. Kljub temu so meje volilnih enot v večji meri še vedno usklajene $\mathrm{z}$ občinskimi mejami (slika 2). Le štiri občine so razdeljene na dve volilni enoti, in sicer: Ljubljana, Pesnica, Trbovlje in Šentrupert. Medtem ko je delitev prve posledica njene velikosti in razdeljenosti na več občin leta 1992, je delitev preostalih treh posledica reform lokalne samouprave v obdobju 1994-2014.

Stopnjo geografske zaokroženosti volilnih enot lahko ocenimo tudi na regionalni ravni. Ker nimamo institucionaliziranih regij, lahko stopnjo geografske zaokroženosti ocenjujemo na podlagi različnih predlogov regionalizacij in sektorskih teritorialnih členitev države. Za slednje je značilna precejšnja neenotnost, saj je v preteklosti vsaka sektorska politika oblikovala svojo teritorialno členitev države (Nared in sod., 2019). Kljub temu lahko na podlagi slike 3 razberemo, katere meje so pomembne regionalne ločnice $\mathrm{v}$ prostoru. Če te primerjamo z mejami volilnih enot, ugotovimo, da pogosto odstopajo od ustaljenih regionalnih delitev. $\mathrm{V}$ nadaljevanju so predstavljene najbolj izrazite anomalije.

Največja anomalija je delitev Osrednjeslovenske regije. Medtem ko sama delitev ni sporna, saj je regija prevelika, da bi tvorila eno samo volilno enoto, je zelo problematična delitev na vzhodni in zahodni del. Z vidika današnje ureditve lokalne samouprave bi bilo bolj smiselno izločiti območje Mestne občine Ljubljana kot samostojno volilno enoto, preostale občine pa bi sestavljale svojo volilno enoto.

Uvrstitev občin Idrija, Cerkno, Kamnik in Komenda v VE 1 s sedežem v Kranju je druga velika anomalija. Medtem, ko prvi dve večina sektorskih delitev uvršča v Goriško oziroma Severnoprimorsko regijo, se drugi dve običajno uvrščata v Osrednjeslovensko regijo.

Tretja anomalija je uvrstitev Zasavja in Laškega v VE $6 \mathrm{~s}$ sedežem v Novem mestu. Zasavje sektorske členitve izločajo kot samostojno regijo ali pa ga uvrščajo v Osrednjeslovensko oziroma Savinjsko regijo. Občina Laško pa je praktično v vseh sektorskih členitvah del Savinjske regije.

Še bolj nenavadna je uvrstitev območja upravne enote Šmarje pri Jelšah (občine Bistrica ob Sotli, Kozje, Podčetrtek, Rogaška Slatina, Rogatec in Šmarje pri Jelšah) v VE 7 $\mathrm{s}$ sedežem v Mariboru. Omenjene občine so v vseh delitvah del Savinjske regije, zaradi česar bi morale biti uvrščene v VE 5 s sedežem v Celju. Enako velja za občine Slovenske Konjice, Zreče in Vitanje, ki funkcijsko prav tako spadajo v Savinjsko regijo, uvrščene pa so v VE 7. Nasprotno velja za koroške občine (Črna na Koroškem, Dravograd, Mežica, Mislinja, Muta, Podvelka, Prevalje, Radlje ob Dravi, Ravne na Koroškem, Ribnica na Pohorju, Slovenj Gradec in Vuzenica). Te so v primeru oblikovanja manjšega števila regij navadno priključene Podravski regiji, zato namesto v VE 5 spadajo v VE 7. Problematična je tudi razmejitev med VE 7 in VE 8, saj so nekatere občine v neposrednem zaledju Maribora (Šentilj in Pesnica) uvrščene v VE 8 s sedežem na Ptuju. 
Slika 2: Ureditev volilnih enot na državnozborskih volitvah.

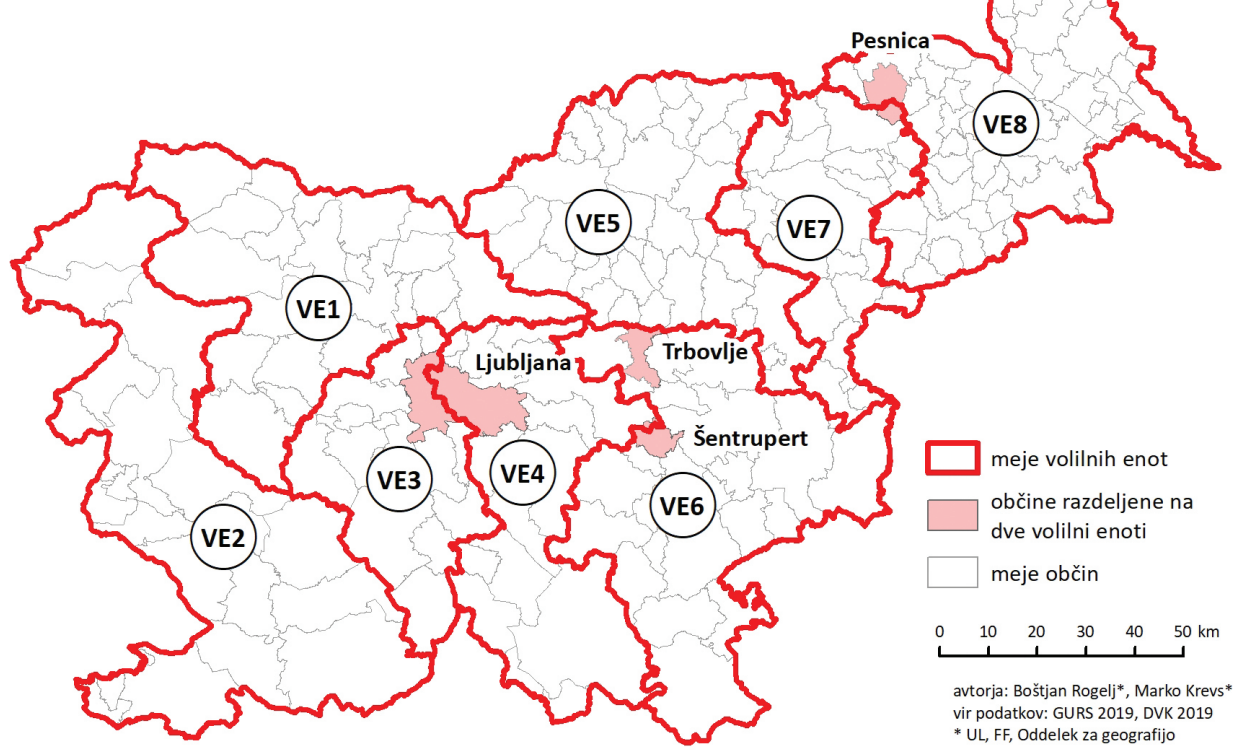

Vir podatkov: GURS, 2019.

Slika 3: Meje sektorskih členitev Slovenije.

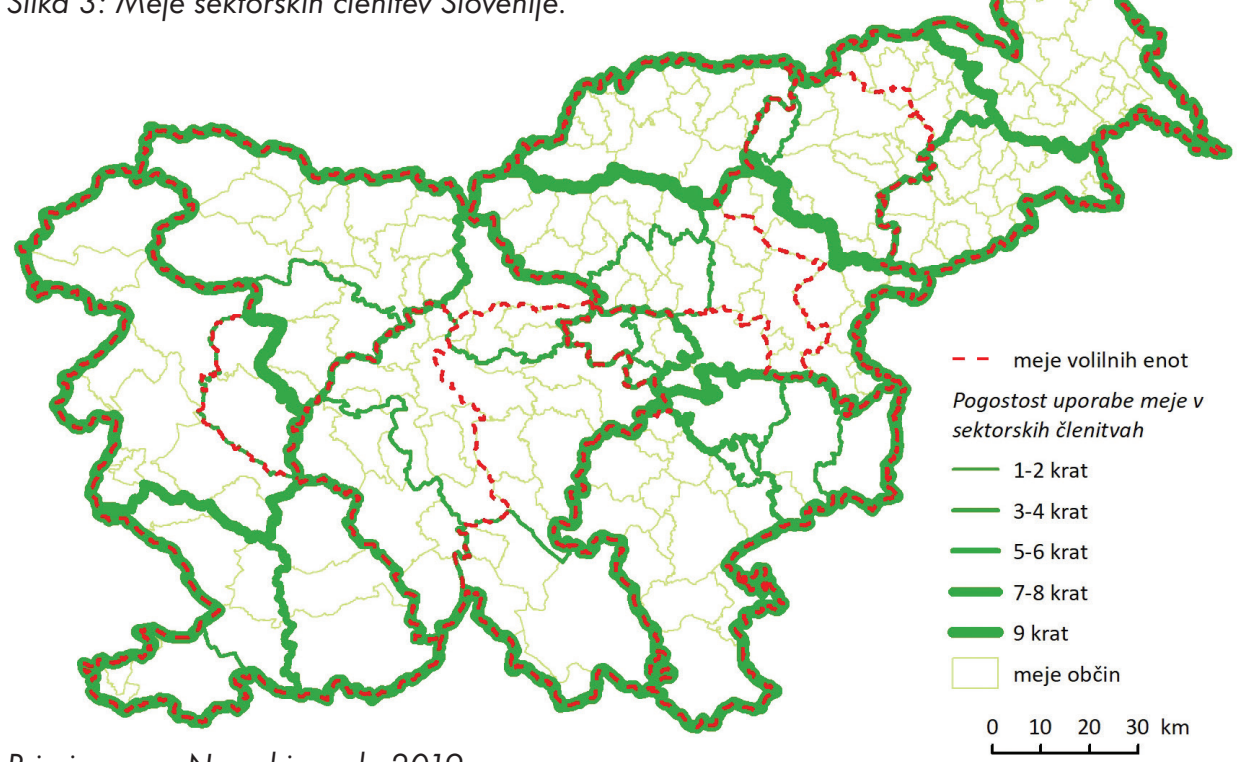


Slika 4: Primeriava ureditve volilnih enot z delitvijo Slovenije na statistične regije $(A)$ ter dvema predlaganima regionalizacijama Slovenije (B, C).
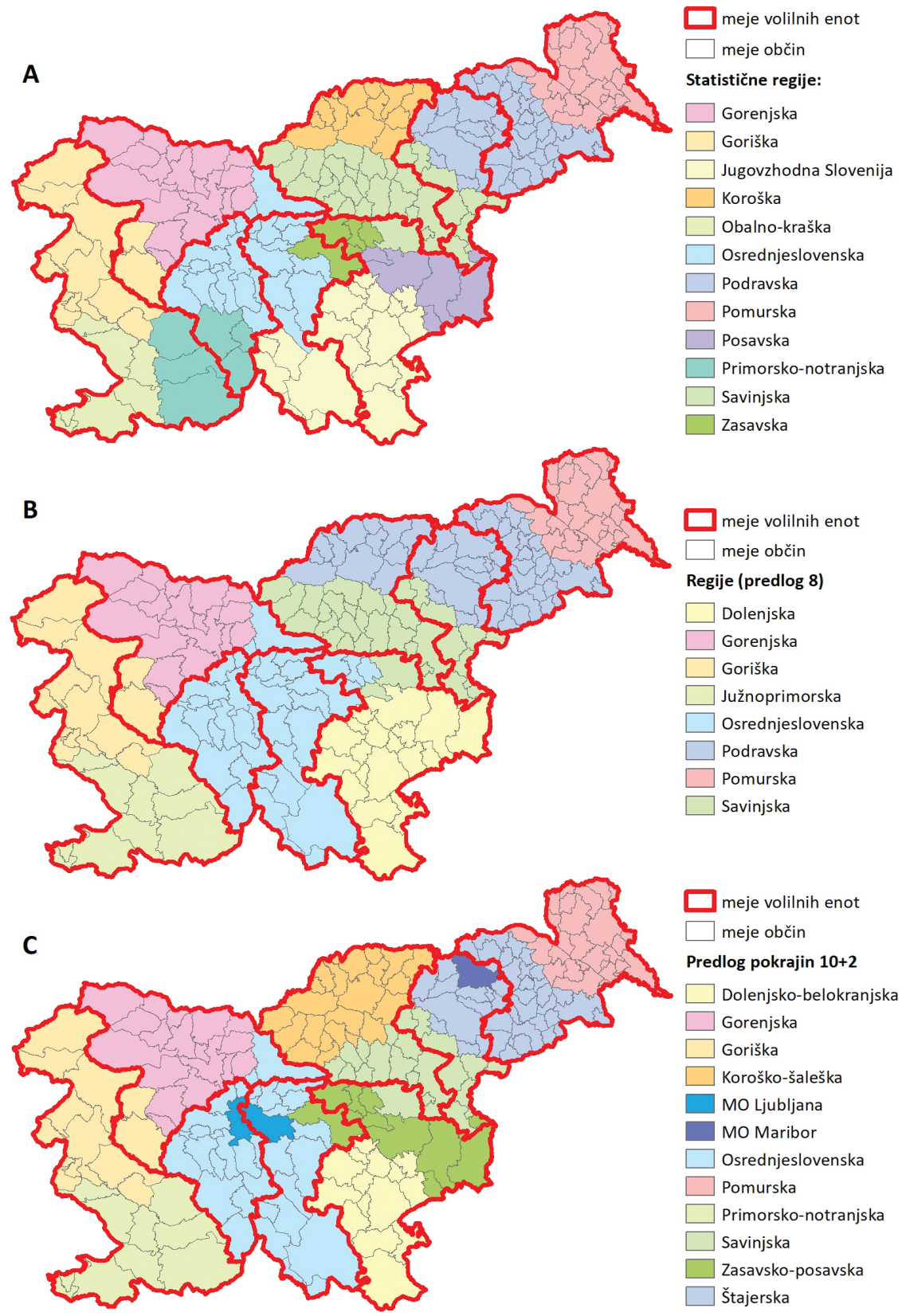

avtor: Boštjan Rogelj*

vir podatkov: GURS 2019, Plut 2004, Drobne 2019

* UL, FF, Oddelek za geografijo 
Podobne anomalije zasledimo, če ureditev volilnih enot primerjamo z različnimi regionalizacijami Slovenije (slika 5). V Sloveniji je bilo v zadnjih petindvajsetih letih narejenih več regionalizacij, ki se med seboj razlikujejo po številu, velikosti in prostorskem obsegu regij/pokrajin. Ureditev volilnih enot le delno sledi mejam predlaganih regij/pokrajin, in to ne glede na izbrano členitev. Številna odstopanja najdemo tako pri primerjavi s členitvijo na manjše število večjih regij/pokrajin kot pri primerjavi z večjim številom manjših regij/pokrajin (Rogelj, 2012, str. 118-120).

Zaradi aktualnosti je še posebno zanimiva primerjava ureditve volilnih enot $\mathrm{z}$ zadnjim predlogom delitve države na deset pokrajin in dve mestni občini (Drobne, 2019). Tudi ta opozarja na večino prej omenjenih anomalij (slika 6), hkrati pa prinaša dve pomembni spremembi. Prva je oblikovanje Koroško-šaleške regije, ki naj bi odražala čedalje večjo funkcionalno navezanost koroških občin na Velenje oziroma Celje. S tem postane umestitev koroških občin v VE 5 bolj smiselna oziroma upravičena. Druga izjema je Zasavje, ki v omenjeni regionalizaciji skupaj s posavskimi občinami in Litijo tvori Zasavsko-posavsko pokrajino. S tem postane umestitev Zasavja v VE 6 bolj utemeljena.

Iz zapisanega je razvidno, da obstoječa ureditev volilnih enot le delno izpolnjuje merila iz 2. in 20. člena ZVDZ ter 2. člena ZDVEDZ. Za ureditev je značilna relativno visoka stopnja spoštovanja načela enake volilne pravice, saj so razlike v številu prebivalcev/volivcev med volilnimi enotami relativno majhne, problematično je le povečevanje teh razlik v zadnjem obdobju. $Z$ vidika geografske zaokroženosti je večina meja volilnih enot še vedno usklajena $\mathrm{z}$ občinskimi mejami, problematična ostaja delitev Mestne občine Ljubljana na dva dela. Ureditev volilnih enot $v$ številnih primerih odstopa od ustaljenih regionalnih delitev Slovenije. Večje anomalije se kažejo tako rekoč $\mathrm{v}$ vseh volilnih enotah.

\section{PREDLOGI SPREMEMB VOLILNIH ENOT V DRŽAVNOZBORSKEM VOLILNEM SISTEMU}

$\mathrm{V}$ nadaljevanju so predstavljeni trije predlogi morebitnih sprememb volilnih enot. Vsak je zasnovan na drugih izhodiščih, posledično ima vsak svoje prednosti in pomanjkljivosti.

Prvi predlog temelji na enakih izhodiščih kot obstoječa ureditev. Državo deli na osem 11-mandatnih volilnih enot, $\mathrm{v}$ katerih je približno enako število volivcev. Zahteva po geografski zaokroženosti volilnih enot je $\mathrm{v}$ tem predlogu podrejena načelu enake volilne pravice. Prostorski obseg volilnih enot se tako prilagaja zahtevi, da je v vseh volilnih enotah približno enako število volivcev.

Drugi predlog je zasnovan na popolnoma drugačnih izhodiščih. Predlog predvideva oblikovanje pokrajinske ravni lokalne samouprave in uskladitev meja volilnih enot $\mathrm{z}$ mejami pokrajin. Temelji na predlogu Teritorialne členitve Slovenije na deset pokrajin s posebnim statusom Mestne občine Ljubljana in Mestne občine Maribor, ki ga je leta 
2019 pripravila skupina strokovnjakov (Državni svet, 2019). Namenjen je predvsem predstavitvi ključnih prednosti in pomanjkljivosti ureditve, ki temelji na velikostno zelo heterogenih volilnih enotah. Pri tem predlogu je prostorski obseg volilnih enot določen vnaprej, njihova velikost (število mandatov) pa se določi na podlagi števila prebivalcev ali volivcev s pomočjo enostavne (Harejeve) kvote in sistema največjega ostanka ${ }^{2}$.

Tretji predlog je nekakšen kompromis oziroma vmesna varianta med prvim in drugim predlogom. Predlog ne določa nespremenljive velikosti volilnih enot, temveč jo omejuje. Predvideva oblikovanje osmih različno velikih volilnih enot, v katerih se voli najmanj devet in največ dvanajst mandatov. $Z$ omejitvijo velikosti se zmanjšuje negativen vpliv zelo majhnih/velikih volilnih enot, povečujeta pa se prilagodljivost pri določitvi njihovega prostorskega obsega in stopnja spoštovanja načela enake volilne pravice. Hkrati se močno zmanjšajo razlike $\mathrm{v}$ naravi strankarskega tekmovanja med posameznimi volilnimi enotami. Velikost volilnih enot se določi po enakem načelu kot pri drugem predlogu (Harejeva kvota in sistem največjega ostanka). Prostorski obseg volilnih enot temelji na predlogih regionalizacije Slovenije na osem oziroma štirinajst regij (Plut, 2004).

\subsection{Predlog osmih enako velikih in geografsko zaokroženih volilnih enot}

Prvi predlog (slika 5) ohranja osem enajstmandatnih volilnih enot. Z odpravo nekaterih najbolj problematičnih anomalij obstoječe ureditve izboljšuje geografsko zaokroženost volilnih enot. Nova razmejitev poskuša čim bolj slediti obstoječim regionalizacijam in sektorskim členitvam države, hkrati pa bistveno ne povečuje razlik $\mathrm{v}$ številu volivcev med posameznimi volilnimi enotami.

Predlog predvideva večje spremembe $\mathrm{v}$ šestih volilnih enotah. Iz VE 1 se izločita občini Cerkno in Idrija, vanjo pa se vključita občini Medvode in Vodice. Razlogi za izločitev prvih dveh so bili že navedeni. Vključitev zadnjih dveh je nujna zaradi zagotavljanja enakega števila volivcev v vseh volilnih enotah. Njuna vključitev v »Gorenjski« volilni okraj ni neproblematična, saj sta obe občini funkcijsko bolj navezani na Ljubljano oziroma na Osrednjeslovensko regijo kot na Kranj in Gorenjsko regijo. $\mathrm{Na}$ drugi strani pa velja, da je med prebivalci relativno močno prisotna "gorenjska" identiteta oziroma identifikacija z Gorenjsko (Polič, 2002).

VE 2 se razširi na občini Cerkno in Idrija, ki tako funkcionalno kot identitetno spadata v Primorsko oz. Goriško regijo. Sprememba zmanjšuje stopnjo spoštovanja načela enake volilne pravice, saj se število volivcev v volilni enoti nevarno približa 5-odstotnemu odstopanju.

Največje spremembe so predvidene v VE 3 in VE 4, kjer se na območju Mestne

2 Enostavna oziroma Harejeva kvota je količnik, ki ga dobimo, če število prebivalcev oziroma volivcev na celotnem ozemlju, kjer potekajo volitve, delimo s številom vseh mandatov. Število mandatov v posamezni volilni enoti je enako količniku med številom prebivalcev oziroma volivcev v enoti in »enostavno kvoto«. Nerazdeljeni mandati se razdelijo med volilne enote po metodi največjega ostanka. 
občine Ljubljana oblikuje nova VE 4, preostale občine brez Medvod in Vodic pa tvorijo novo VE 3. Omenjena sprememba bi odpravila največjo anomalijo obstoječe ureditve ter $\mathrm{v}$ celoti uskladila meje volilnih enot $\mathrm{z}$ občinskimi mejami.

Večjih sprememb je deležna razmejitev med VE 5 in VE 7. Občine iz Koroške statistične regije se iz prve prestavijo v drugo, občine Bistrica ob Sotli, Kozje, Podčetrtek, Rogaška Slatina, Rogatec in Šmarje pri Jelšah ter Slovenske Konjice, Zreče in Vitanje pa postanejo del VE 5 . S tem bi se prostorski obseg VE $5 \mathrm{v}$ večji meri uskladil z obsegom Savinjske statistične regije (izjemi bi bili le občini Laško in Bistrica ob Sotli). VE 7 postane bolj geografsko zaokrožena, saj obsega Koroško in del Podravske statistične regije. Na drugi strani bi sprememba močno ogrozila načelo enake volilne pravice (preglednica 3). Omenjen problem bi lahko rešili s prestavitvijo ene večje občine iz VE 7 v VE 5, vendar bi s tem povzročili nove anomalije, ki jih predlog odpravlja.

VE $6 \mathrm{~s}$ sedežem v Novem mestu in VE $8 \mathrm{~s}$ sedežem na Ptuju sta deležni le manjših kozmetičnih popravkov. V obeh primerih so meje volilnih enot usklajene z mejami občin. Tako občini Trbovlje in Šentrupert v celoti postaneta del VE 6, občina Pesnica pa del VE 8.

Glavna prednost prvega predloga je, da je oblikovan skladno z 20. členom ZVDZ. Za njegovo uveljavitev bi bilo treba spremeniti le ZDVEDZ. V primerjavi z obstoječo ureditvijo ponuja geografsko bolj zaokrožene volilne enote, saj odpravlja večino najbolj problematičnih rešitev sedanje ureditve.

Glavna slabost predloga so velike razlike $\mathrm{v}$ številu volivcev med posameznimi volilnimi enotami, zaradi česar se zmanjšuje spoštovanje načela enake volilne pravice. Po predlogu bi dve volilni enoti presegli 5-odstotni prag odstopanja, dve pa bi se temu pragu močno približali (glej preglednico 3). Problem bi lahko delno rešili, če bi zmanjšali geografsko zaokroženost nekaterih enot, pri čemer se poraja dvom o smiselnosti spreminjanja obstoječe ureditve. Drugi problem je, da predlog ne odpravlja vseh anomalij sedanje ureditve, zaradi česar volilne enote niso geografsko zaokrožene. Problematične ostajajo vključitev nekaterih občin (Kamnik, Komenda, Medvode in Vodice) iz Osrednjeslovenske regije v VE 1, vključitev občine Laško v VE 6 ter vključitev občin Kungota, Pesnica in Šentilj v VE 8. 
Slika 5: Prvi predlog ureditve z osmimi enako velikimi in geografsko boli zaokroženimi volilnimi enotami.

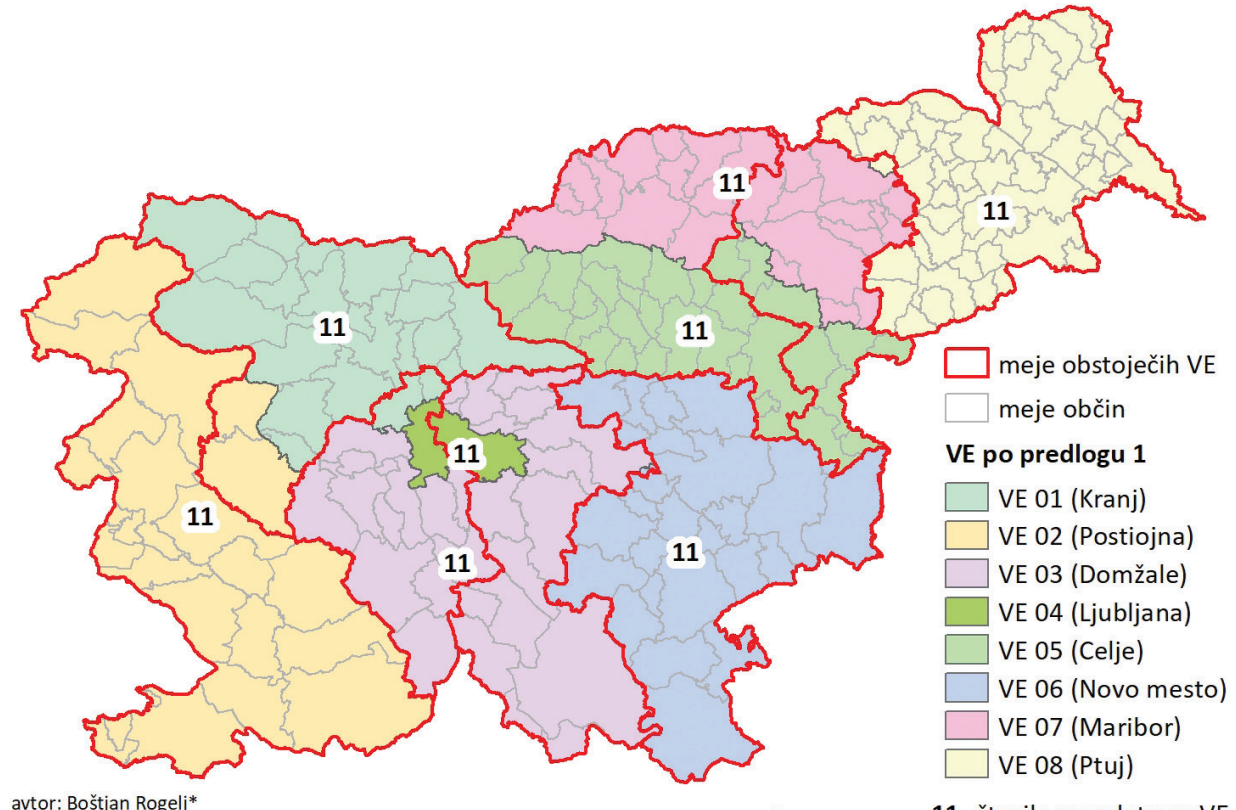

vir podatkov: GURS 2019

UL, FF, Oddelek za geografijo

$\begin{array}{r}0 \quad 10 \quad 20 \quad 30 \quad 40 \\ \hline\end{array}$

11 število mandatov $\mathrm{V} V E$

Preglednica 3: Prvi predlog: število mandatov in število volivcev po volilnih enotah.

\begin{tabular}{|l|c|c|c|}
\hline Ime VE & Število mandatov & Število volivcev & Odstopanje (v \%) \\
\hline VE 01 (Kranj) & 11 & 212.674 & $-0,12$ \\
\hline VE 02 (Postojna) & 11 & 223.456 & 4,94 \\
\hline VE 03 (Domžale) & 11 & 206.652 & $-2,95$ \\
\hline VE 04 (Ljubljana) & 11 & 220.954 & 3,77 \\
\hline VE 05 (Celje) & 11 & 200.552 & $-5,81$ \\
\hline VE 06 (Novo mesto) & 11 & 202.511 & $-4,89$ \\
\hline VE 07 (Maribor) & 11 & 224.003 & 5,20 \\
\hline VE 08 (Ptuj) & 11 & 212.662 & $-0,13$ \\
\hline skupaj & 88 & 1.703 .464 & - \\
\hline
\end{tabular}

Vir podatkov: MNZ, 2019. 


\subsection{Predlog dvanajstih različno velikih volilnih enot}

Drugi predlog predvideva ustanovitev dvanajstih velikostno zelo različnih volilnih enot, ki sovpadajo s členitvijo Slovenije na deset pokrajin in dve mestni občini s posebnim statusom, ki jo je leta 2019 pripravila strokovna skupina (Državni svet, 2019). Večina predlaganih volilnih enot je relativno majhnih, zato se $\mathrm{v}$ njih praviloma voli manj kot deset mandatov (slika 6).

Po predlogu je VE 1 omejena na Gorenjsko statistično regijo. Iz nje se izločita občini Cerkno in Idrija, ki postaneta del VE 2, ter Kamnik in Komenda, ki bi se premaknili v VE 3. Območje obstoječe volilne enote 2 se razdeli na dve volilni enoti (VE 2 in VE 3). Tudi po tem predlogu se na območju Mestne občine Ljubljana oblikuje samostojna volilna enota (VE 5), preostale osrednjeslovenske občine pa tvorijo VE 4 (izjema je občina Litija, ki postane del VE 7). Obstoječi volilni enoti 5 in 6 se razdelita na dva dela. Enako kot Ljubljana bi tudi Mestna občina Maribor tvorila svojo volilno enoto (VE 11), meje VE 10 in VE 12 pa bi se uskladile z mejami Podravske (brez MO Maribor) in Pomurske statistične regije.

Uskladitev meja pokrajin in volilnih enot ter oblikovanje relativno majhnih volilnih enot povečujeta geografsko reprezentativnost volilnega sistema in omogočata tesnejšo povezanost poslancev in volivcev. Majhne geografsko zaokrožene volilne enote odpravljajo potrebo po delitvi volilnih enot na volilne okraje, saj tudi manjšim regijam zagotavljajo zastopanost v Državnem zboru in hkrati omogočajo lažjo izvedbo preferenčnega glasovanja, saj imajo volivci boljši pregled nad kandidati. Poznavanje kandidatov hkrati zmanjša verjetnost, da bi večina poslancev prišla iz večjih središč oziroma da bi bili izvoljeni le medijsko prepoznavni kandidati.

Največji problem drugega predloga je kršenje načela enake volilne pravice. Ker je več manjših volilnih enot, prihaja do večjih odstopanj pri številu volivcev, ki volijo en mandat. Iz preglednice 4 je razvidno, da $\mathrm{v}$ posameznih primerih odstopanja lahko presežejo $10 \%$. Pri tem velja opozoriti, da že manjše spremembe v prostorski razporeditvi volivcev lahko pomembno vplivajo na razdelitev mandatov po volilnih enotah. Oblikovanje pravičnega in preglednega sistema delitve mandatov igra pri tem predlogu ključno vlogo.

Velikostno zelo heterogene volilne enote bi pomembno vplivale na naravo strankarskega tekmovanja. Predvsem bi vplivale na znotrajstrankarsko tekmovanje za mandate. Ob uveljavitvi drugega predloga in ohranitvi obstoječega sistema delitve mandatov lahko pričakujemo, da se bo zaradi višjega dejanskega volilnega praga (preglednica 1) zmanjšal delež mandatov, ki so razdeljeni pri delitvi na ravni volilnih enot. Tako bo v Državni zbor prišlo več poslancev, ki bodo mandat pridobili na nacionalni ravni. Ker pri delitvi na nacionalni ravni uspešnost posameznega kandidata $\mathrm{v}$ okviru stranke ni več odločilna, se bo povečal delež izvoljenih poslancev, ki na lastni listi/v stranki ne bodo imeli visoke podpore (glej Rogelj, 2011). Zaradi dvonivojske delitve mandatov in prostorske razpršenosti majhnih volilnih enot ni pričakovati, da bi ureditev v večji meri vplivala na medstrankarsko delitev mandatov. 
Slika 6: Drugi predlog ureditve z dvanajstimi različno velikimi volilnimi enotami.

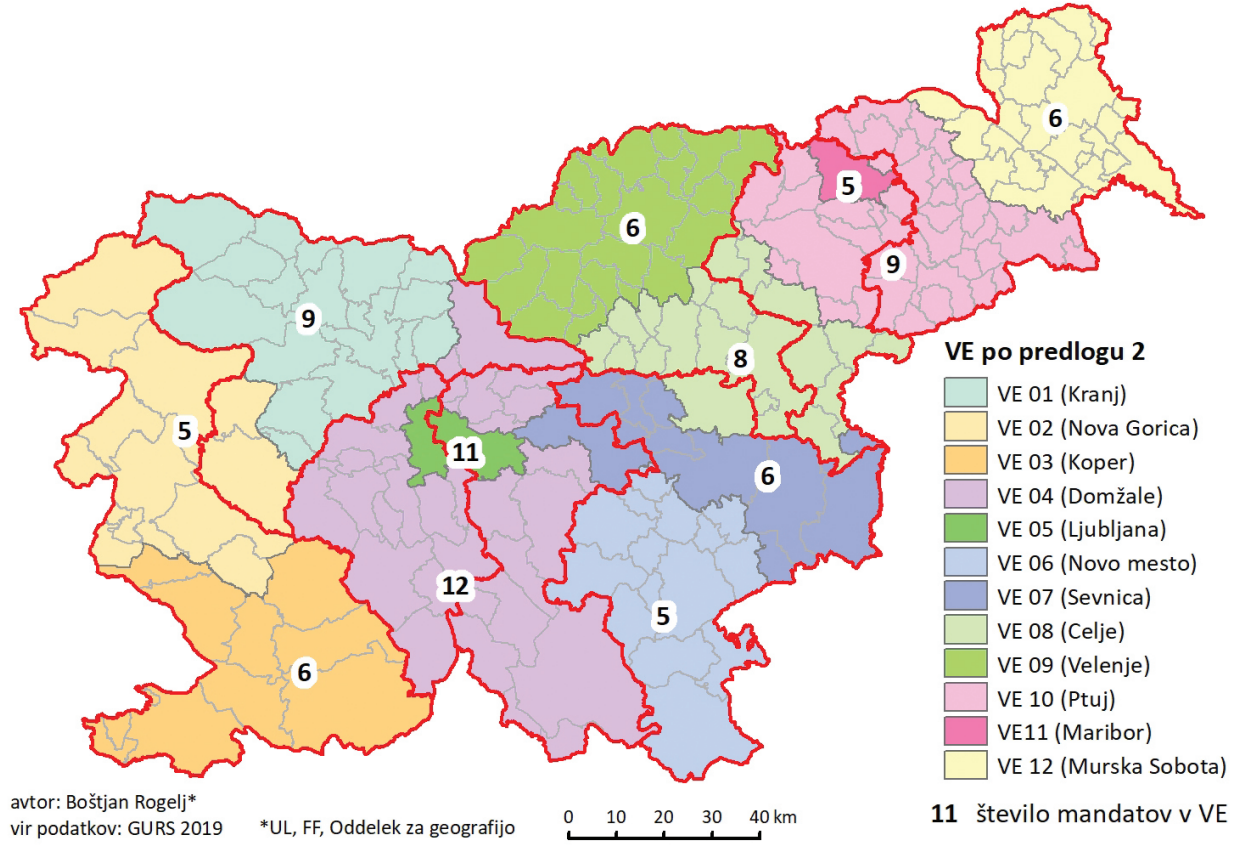

Preglednica 4: Drugi predlog: število mandatov in število volivcev po volilnih enotah.

\begin{tabular}{|l|c|c|c|}
\hline Ime VE & Število mandatov & Število volivcev & Odstopanje (v \%) \\
\hline VE 01 (Kranj) & 9 & 167.776 & 3,84 \\
\hline VE 02 (Postojna) & 5 & 99.898 & $-3,11$ \\
\hline VE 03 (Koper) & 6 & 123.558 & $-6,00$ \\
\hline VE 04 (Domžale) & 12 & 239.011 & $-2,81$ \\
\hline VE 05 (Ljubljana) & 11 & 220.954 & $-3,63$ \\
\hline VE 06 (Novo mesto) & 5 & 92.324 & 4,84 \\
\hline VE 07 (Sevnica) & 6 & 112.652 & 3,10 \\
\hline VE 08 (Celje) & 8 & 161.208 & $-3,94$ \\
\hline VE 09 (Velenje) & 6 & 109.851 & 5,73 \\
\hline VE 10 (Ptuj) & 9 & 180.997 & $-3,74$ \\
\hline VE 11 (Maribor) & 5 & 89.740 & 7,86 \\
\hline VE 12 (Murska Sobota) & 6 & 105.495 & 10,10 \\
\hline skupaj & 88 & 1.703 .464 & - \\
\hline
\end{tabular}

Vir podatkov: MNZ, 2019. 


\subsection{Predlog osmih različno velikih in geografsko zaokroženih volilnih enot}

Tretji predlog je kompromis med prvim in drugim predlogom. Namesto osmih enako velikih predvideva oblikovanje osmih različno velikih volilnih enot. Različna velikost omogoča oblikovanje geografsko bolj zaokroženih volilnih enot, ki v večji meri sledijo sektorskim členitvam in predlaganim regionalizacijam Slovenije. Tako oblikovane volilne enote ohranjajo visoko stopnjo spoštovanja načela enake volilne pravice ter zmanjšujejo negativen vpliv velikih razlik v velikosti volilnih enot.

Predlog predvideva spremembe vseh obstoječih volilnih enot. Enako kot pri drugem predlogu bi bila VE 1 omejena na Gorenjsko statistično regijo, v njej pa bi se volilo le devet mandatov. Tako bi iz nje izločili občini Cerkno in Idrija, ki bi postali del VE 2, ter Kamnik in Komendo, ki bi se premaknili v VE 3.

Tudi po tem predlogu bi se na območju Mestne občine Ljubljana oblikovala samostojna volilna enota. Večina občin iz obstoječe VE 3 in VE 4 skupaj z občinama Kamnik in Komenda tvorijo novo VE 3, v kateri se voli dvanajst mandatov. Izjema sta občini Litija in Šmartno pri Litiji, ki se priključita k VE 6 s sedežem v Novem mestu. Litija je leta 2015 postala del Zasavske statistične regije in posledično se razvojno in funkcionalno čedalje bolj povezuje $\mathrm{z}$ drugimi občinami v regiji. V Zasavsko-posavsko pokrajino jo uvršča tudi zadnji predlog oblikovanja pokrajin v Sloveniji (Drobne, 2019). Šmartno pri Litiji še vedno spada v Osrednjeslovensko statistično regijo, vendar pa je funkcionalno tako tesno povezano $\mathrm{z}$ občino Litija, da bi bila njuna uvrstitev $\mathrm{v}$ dve različni volilni enoti problematična.

VE 5 obsega celotno Savinjsko statistično regijo vključno $\mathrm{z}$ občino Laško. Z njeno vključitvijo se odpravi problem premajhnega števila volivcev, ki je bil omenjen pri prvem predlogu. Izločitev Laškega in priključitev Litije in Šmartnega pri Litiji sta ključni spremembi v VE 6. Enako kot v prvem predlogu se zaradi uskladitve meje volilnih enot z mejami občin Trbovlje in Šentrupert v celoti premakneta v VE 6.

VE 7 je podobno urejena kot v prvem predlogu. Obsega celotno Koroško in del Podravske statistične regije. V nasprotju s prvim predlogom obsega tudi občine Kungota, Pesnica in Šentilj. Zaradi večjega števila volivcev se v njej voli dvanajst mandatov. Nasprotno velja za VE 8, ki se zaradi premika omenjenih občin zmanjša, zato se v njej voli le deset mandatov. Meja med VE 7 in VE 8 sledi meji med Zgornjepodravsko in Spodnjepodravsko regijo, kot jo predvideva Plutova delitev države na štirinajst regij (Plut, 2004).

Velika geografska zaokroženost volilnih enot je glavna prednost tretjega predloga. Omenjeni predlog odpravlja vse anomalije obstoječe ureditve in z izjemo delitve Podravja sledi ustaljenim regionalnim delitvam in sektorskim členitvam države. Druga prednost predloga je visoka stopnja spoštovanja načela enake volilne pravice. Iz preglednice 5 je razvidno, da so odstopanja zelo majhna. Omejitev velikosti najmanjših volilnih enot in prilagajanje velikosti številu volivcev močno zmanjšuje verjetnost velikih odstopanj. 
Pomembno je tudi, da so relativno velike volilne enote manj izpostavljene spremembam v prostorski razporeditvi prebivalstva. Posledično lahko pričakujemo, da bo velikost volilnih enot bolj konstantna in redkeje izpostavljena reviziji. Kljub temu tudi ta predlog zahteva oblikovanje pravičnega in preglednega sistema delitve mandatov med volilnimi enotami.

Med pomanjkljivostmi predloga velja opozoriti na razlike v naravi strankarskega tekmovanja, ki so značilne za ureditve $\mathrm{z}$ različno velikimi volilnimi enotami. Pri tem je treba poudariti, da razlike zaradi dvonivojske delitve mandatov in majhnih razlik v velikosti volilnih enot ne bi močneje vplivale na delitev mandatov med strankami, $\mathrm{v}$ manjši meri bi verjetno vplivale na znotrajstrankarsko delitev mandatov.

Verjetno je največji problem tega predloga dejstvo, da bi bilo za njegovo sprejetje treba spremeniti ZVDZ, za kar pa je potrebna dvotretjinska večina (66 glasov) poslanskih glasov v Državnem zboru.

Slika 7: Tretji predlog ureditve z osmimi različno velikimi in geografsko zaokroženimi volilnimi enotami.

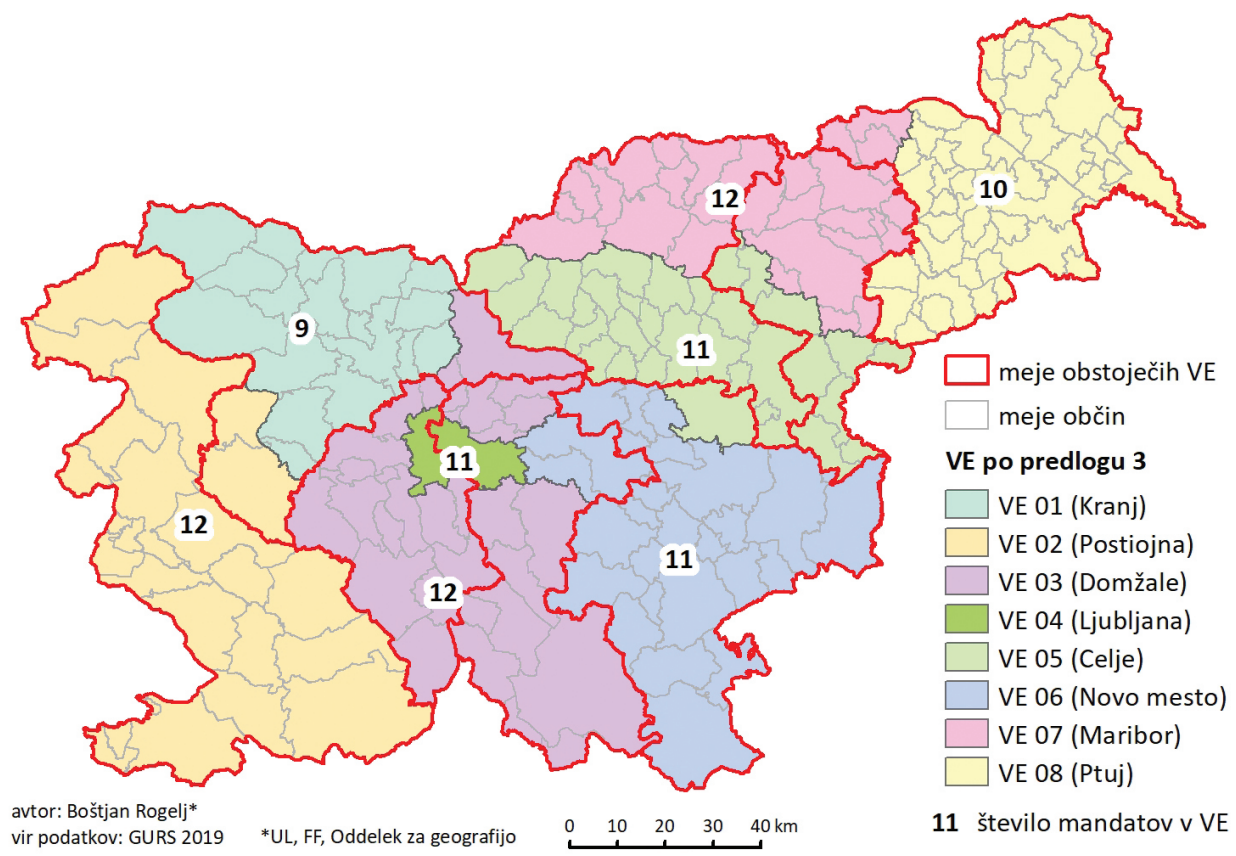


Preglednica 5: Tretji predlog: število mandatov in število volivcev po volilnih enota.

\begin{tabular}{|l|c|c|c|}
\hline Ime VE & Število mandatov & Število volivcev & Odstopanje (v \%) \\
\hline VE 01 (Kranj) & 9 & 167.776 & 3,84 \\
\hline VE 02 (Postojna) & 12 & 223.456 & 3,95 \\
\hline VE 03 (Domžale) & 12 & 234.550 & $-0,96$ \\
\hline VE 04 (Ljubljana) & 11 & 220.954 & $-3,63$ \\
\hline VE 05 (Celje) & 11 & 211.898 & 0,49 \\
\hline VE 06 (Novo mesto) & 11 & 208.165 & 2,29 \\
\hline VE 07 (Maribor) & 12 & 241.873 & $-3,96$ \\
\hline VE 08 (Ptuj) & 10 & 194.792 & $-0,62$ \\
\hline skupaj & 88 & 1.703 .464 & - \\
\hline
\end{tabular}

Vir podatkov: MNZ, 2019.

\section{SKLEP}

Odločba Ustavnega sodišča U-I-32/15-56 iz novembra 2018 je znova oživila razpravo o reformi državnozborskega volilnega sistema. V njej sta se oblikovala dva predloga sprememb volilnega sistema. Prvi predvideva uvedbo relativnega prednostnega glasu in odpravo volilnih okrajev. Drugi predvideva preoblikovanje meja volilnih okrajev. Za oba je značilno, da ne predvidevata bistvenih sprememb v ureditvi volilnih enot.

Analiza obstoječe ureditve volilnih enot je pokazala, da ta le delno izpolnjuje merila iz 2. in 20. člena ZVDZ ter 2. člena ZDVEDZ. Problematične so čedalje večje razlike $\mathrm{v}$ številu prebivalcev/volivcev med volilnimi enotami, delitev Mestne občine Ljubljana in treh drugih občin na več volilnih enot ter neusklajenost meja volilnih enot $\mathrm{z}$ uveljavljenimi regionalnimi in sektorskimi členitvami države. Zadnja je še posebej problematična, saj volivcem in poslancem otežuje, da bi se identificirali z volilno enoto, $v$ kateri glasujejo/so izvoljeni. Čeprav v volilnih enotah poteka primarna delitev mandatov, se volivci in poslanci le redko identificirajo z njimi. Pogosteje se identificirajo z volilnimi okraji, čeprav v njih ne poteka medstrankarska delitev mandatov. Vzroke za to lahko iščemo v specifični ureditvi personifikacije $\mathrm{z}$ glasovanjem po volilnih okrajih (Gaber, 1996; Pogorelec, 1998; Ribičič, 1996), delno pa v dejstvu, da je za volilne okraje značilna visoka stopnja geografske zaokroženosti (Rogelj, 2012).

$\mathrm{V}$ članku predstavljeni predlogi alternativne ureditve volilnih enot dokazujejo, da je mogoče oblikovati geografsko veliko bolj zaokrožene volilne enote, ki hkrati ohranjajo relativno visoko stopnjo spoštovanja načela enake volilne pravice (izjema je drugi predlog).

$\mathrm{Na}$ koncu velja predstavljene predloge alternativne ureditve volilnih enot umestiti v trenutno razpravo o reformi državnozborskega volilnega sistema. Omenjeno je bilo, da sta se v dosedanji razpravi oblikovala dva predloga. Prvi predvideva preoblikovanje 
meja volilnih okrajev. Drugi predvideva odpravo volilnih okrajev in uvedbo relativnega prednostnega glasu. $\mathrm{V}$ času pisanja članka noben predlog nima zagotovljene zadostne podpore v Državnem zboru.

Prvi predlog ne predvideva temeljitejših sprememb volilnega sistema, zato je tudi večja reforma ureditve volilnih enot manj smiselna in teže izvedljiva. Med tremi predlogi ureditve volilnih enot le prvi ne zahteva korenitejših sprememb volilnega sistema (za njegovo uveljavitev ni treba posegati v ZVDZ, dovolj bi bila sprememba ZDVEDZ). Zato bi bilo pri preoblikovanju volilnih okrajev smiselno razmisliti o tem predlogu. Prvi predlog enako kot obstoječi sistem predvideva osem enako velikih volilnih enot. Te bi bile geografsko bolj zaokrožene, kot so obstoječe, hkrati pa bi se bolj razlikovale po številu volivcev. Za prvi predlog je značilno, da povečuje geografsko zaokroženost volilnih enot na račun stopnje spoštovanja načela enake volilne pravice. Zato bi bila uveljavitev drugačne ureditve volilnih enot odvisna od tega, kateremu merilu iz 20. člena ZVDZ daje zakonodajalec večjo težo.

Uvedba relativnega preferenčnega glasovanja in odprava volilnih okrajev bi odprla vrata za temeljitejšo reformo ureditve volilnih enot. Med drugim bi omogočila spremembo 2. člena ZVDZ, ki določa, da je država razdeljena na osem enako velikih volilnih enot. Oblikovanje velikostno heterogenih volilnih enot predvidevata drugi in tretji predstavljeni predlog. Uveljavitev drugega predloga je smiselna le ob ustanovitvi pokrajin. Pokrajine bi upravičile velike razlike v velikosti volilnih enot ter dale majhnim volilnim enotam potrebno legitimnost. Ob odsotnosti pokrajinske ravni oblasti bi bilo oblikovanje majhnih volilnih enot dvomljivo. Nizka stopnja spoštovanja načela enake volilne pravice in drugi problemi majhnih volilnih enot ne odtehtajo tega, da je v njih laže izvesti preferenčno glasovanje in da ima le-to navadno večji vpliv na volilne rezultate. Glede na zgodovino sprejemanja pokrajinske ravni lokalne samouprave v Sloveniji in različne poglede na predlagano regionalizacijo je malo verjetno, da bodo v bližnji prihodnosti ustanovljene pokrajine.

Bolj realno in smiselno bi bilo sprejeti tretji predlog. Uskladitev volilnih enot z ustaljenimi regionalnimi delitvami Slovenije bi bila v volilnem sistemu, zasnovanem na preferenčnem glasovanju, še pomembnejša kot $\mathrm{v}$ obstoječem sistemu, saj bi pripomogla $\mathrm{k}$ tesnejši povezanosti med volivci in poslanci. Volivci bi poslance laže dojeli kot predstavnike "njihove« regije oz. pokrajine. $Z$ oblikovanjem ločene »ljubljanske« volilne enote in ohranitvijo relativno velikih volilnih enot predlog preprečuje, da bi večina izvoljenih kandidatov prihajala iz večjih regionalnih središč. Tretji predlog predvideva zelo majhne razlike $\mathrm{v}$ velikosti volilnih enot, zato se narava strankarskega tekmovanja in delež poslancev, izvoljenih na ravni volilnih enot, ne bi bistveno spremenila.

Za konec velja opozoriti, da bi bilo treba v primeru kakršnekoli spremembe ureditve volilnih enot $v$ ZVDZ in ZDVEDZ vključiti jasnejša merila glede njihovega oblikovanja. Nujno bi bilo določiti dovoljena odstopanja v številu volivcev med posameznimi volilnimi enotami ter natančneje opredeliti merila, na podlagi katerih se ocenjuje geografska zaokroženost volilnih enot. S tem bi se izognili različnim interpretacijam 
zakonodaje, ki smo jim priča $\mathrm{v}$ trenutni razpravi o reformi volilnega sistema. Prav tako bi bilo treba natančno določiti, kdaj oziroma v katerih primerih je treba ureditev volilnih enot spremeniti. Če bi se uveljavila rešitev, ki predvideva različno velikost volilnih enot, bi bilo treba določiti jasen in pravičen način delitve mandatov med volilne enote, saj je to predpogoj za pravične in poštene volitve.

Reforma ureditve volilnih enot ni nujno potrebna, je pa smiselna, še zlasti če bi bilo uveljavljeno preferenčno glasovanje.

\section{Literatura in viri}

ACE Project, 2020a. Equal population redistricting. URL: http://aceproject.org/aceen/topics/bd/bdb/bdb05/bdb05a (citirano 9. 6. 2020).

ACE Project, 2020b. Electoral system and ballot type implications for the count. URL: https://aceproject.org/ace-en/topics/vc/vca/default (citirano 9. 6. 2020).

Beneška komisija, 2002. Code of good practice in electoral matters: guidelines and explanatory report (Opinion no. 190/2002). Strasbourg.

Beneška komisija, 2013. Electoral law (CDL-EL 2013/006). Strasbourg.

Drobne, S., 2019. Funkcionalne regije kot podlaga za ustanovitev pokrajin v Sloveniji. Ljubljana. URL: http://www.pokrajine.si/wp-content/uploads/2019/10/DROBNE-2019-10-05-FR-kot-podlaga-Za-ustanovitev-pokrajin-v-Sloveniji-1.pdf (citirano 9.6.2020).

Državni svet, 2019. Ustanovitev pokrajin v Sloveniji. http://www.pokrajine.si/ (citirano 9. 6. 2020).

Farrell, D. M., 2001. Electoral systems: a comparative introduction. New York: Palgrave. Gaber, S., 1996. Volilni sistemi: zbornik. Ljubljana: Krtina.

Handley, L., Jeremy, G., Schrott, P., Boneo, H., Johnston, R., Maley, M., McRobie, A., Pattie, C., Rossiter, D., Watson, P., 2006. Delimitation equity project: Resource guide. Arlington: International Foundation for Electoral Systems (IFES).

IFES, 2019. Electoral code of the Republic of North Macedonia: Consolidated version (translated and edited by IFES). URL: https://www.ifes.org/sites/default/files/ electoral_code_of_the_republic_of_north_macedonia_february_2019_english. pdf (citirano 19. 6. 2020).

Krašovec, A., 2007. Volilne študije. Ljubljana: Fakulteta za družbene vede.

Lijphart, A., 1994. Electoral systems and party systems: a study of twenty-seven democracies, 1945-1990. Oxford: Oxford University Press.

Nared, J., Hudoklin, J., Kavaš, D., Zavodnik Lamovšek, A., 2019. Povezovanje prostorskega in razvojnega načrtovanja na regionalni ravni v Sloveniji. Ljubljana: Založba ZRC SAZU.

Plut, D., 2004. Načela, kriteriji in regionalizacija Slovenije z vidika členitve na pokrajine. V: Vlaj, S. (ur.). Pokrajina: druga raven lokalne samouprave. Ljubljana: Inštitut za lokalno samoupravo pri Fakulteti za upravo, str. 21-35. 
Pogorelec, J., 1998. Sistem volitev v Državni zbor: nekaj predlogov za njegovo izboljšanje. Pravna praksa, 17, 14/15, str. 29-38.

Pogorelec, J., 2000. Večinski volilni sistem - trda šola demokracije. Pravna praksa, 19, 7, str. 17-26.

Polič, M., 2002. Spoznavni zemljevid Slovenije. Ljubljana: Znanstveni inštitut Filozofske fakultete.

Ribičič, C., 1996. Osebnost kandidatov in sorazmerna zastopanost strank. V: Gaber, S. (ur.). Volilni sistemi. Ljubljana: Krtina, str. 283-303

Ribičič, C., 1999. Volilni sistem iz žabje perspektive. Teorija in praksa, 36, 3, str. 458471.

Rogelj, B., 2011. Političnogeografska analiza volilnega sistema volitev v Državni zbor Republike Slovenije : doktorska disertacija. Ljubljana: Univerza. Univerza v Ljubljani.

Rogelj, B., 2012. Ureditev volilnih enot v državnozborskem volilnem sistemu. Dela, 37, str. 107-128.

RTVSLO, 2019. Posvet pri Pahorju: Poprava volilnih okrajev ali njihova ukinitev in uvedba preferenčnega glasu? URL: https://www.rtvslo.si/slovenija/posvet-pri-pahorju-poprava-volilnih-okrajev-ali-njihova-ukinitev-in-uvedba-preferencnega-glasu/483334 (citirano 19. 10. 2020).

Strøm, K., Müller, W. C., Bergman, T. (ur.), 2006. Delegation and accountability in parliamentary democracies. Oxford: Oxford University Press.

Uberoi, E., Baker, C., Cracknell, R., Allen, G., Roberts, N., Barton, C., Sturge, G., Danechi, S., Harker, R., Bolton, P., McInnes, R., Watson, C., Dempsey, N., Audickas, L., 2020. General Election 2019: full results and analysis. Briefing Paper CBP 8749. London: House of Commons Library.

Ustavno sodišče RS, 1992. Odločba U-I-128/92. Ljubljana.

Ustavno sodišče RS, 2003. Odločba U-I-226/00. Ljubljana.

Ustavno sodišče RS, 2018. Odločba U-I-32/15-56. Ljubljana.

Webster, G. R., 2013. Reflections on current criteria to evaluate redistricting plans. Political Geography, 32, 1, str. 3-14. DOI: 10.1016/j.polgeo.2012.10.004.

Zakon o določitvi volilnih enot za volitve poslancev v državni zbor [ZDVEDZ]. 2005. Uradni list RS, 24/05.

Zakon o izborima zastupnika u Hrvatski državni Sabor. 2019. Narodne novine. URL: https://zakon.hr/z/355/Zakon-o-izborima-zastupnika-u-Hrvatski-sabor (citirano 20. 6. 2020).

Zakon o volitvah v državni zbor [ZVDZ]. 2017. Uradni list RS, 23/17. 


\section{CHANGES OF ELECTORAL UNITS FOR THE CONDUCT OF ELECTIONS TO THE NATIONAL ASSEMBLY OF THE REPUBLIC OF SLOVENIA}

\section{Summary}

Decision U-I-32/15-56 of the Constitutional Court of November 2018 revived the debate in Slovenia on reforming the National Assembly electoral system. The decision laid out two proposals for changing the electoral system. The first envisages the introduction of a ranked-choice voting system and the abolition of electoral districts. The second envisages the redrawing of electoral districts. Neither of the proposals envisage significant changes in the organization of electoral units. In this article, we want to check whether the existing arrangement of electoral units is in fact unproblematic.

Electoral units are spatial units in which electoral votes are collected and seats are divided in a representative body. Together with the electoral formula, the ballot structure and the electoral threshold, they represent a key element of the electoral system. They are commonly incorporated into proportional representation electoral systems, as a means to ensure great geographical representativeness, closer links between elected representatives (deputies) and voters as well as to simplify the organization of elections (Rogelj, 2012). The size of electoral zones has a significant impact on the degree of proportionality of the division of seats, the nature of party competition and on the extent to which elections conform to the principle of equal suffrage.

Regulation of electoral units for elections to the National Assembly of the Republic of Slovenia is determined by two laws. The National Assembly Elections Act (Official Gazette of the Republic of Slovenia, 2017) stipulates the establishment of eight electoral units, and that eleven deputies are elected in each electoral unit (see Figure 2) and that electoral units are formed in accordance with the principle that one deputy votes on behalf of approximately the same number of residents. The law also stipulates that districting of electoral units and districts must take into account their geographical integrity and common cultural and other characteristics. The spatial dimensions of electoral units are determined by the Act on the Determination of Constituencies for Elections of Deputies to the National Assembly (Official Gazette of the Republic of Slovenia, 2005).

Electoral units were formed in 1992 on the basis of the then administrative division of the state. Since then, there have been significant changes in the spatial distribution of the population, administrative management and spatial development of Slovenia. Analysis of the existing organization of electoral units has shown that it only partially meets the legal criteria. In this regard there are a number of problematic issues, including: increasing disparities in the number of inhabitants/voters between electoral units (Figure 1); the division of the City of Ljubljana and three other municipalities into several electoral units (Figure 2); and discrepancies between electoral unit boundaries and established 
regional and sectoral divisions of the state (Figure 3 ). The latter is particularly problematic as it makes it difficult for voters and deputies to identify with the electoral unit in which they are voting/elected. Despite the primary division of seats being determined in electoral units, voters and deputies rarely identify with them.

The article presents three proposals to alternatively administer electoral units. The proposals are based on different starting points, so they each have different advantages and disadvantages.

The first proposal (Figure 5 and Table 3 ) builds on the same starting points as the existing regulations and conforms to existing legislation. It divides the country into eight 11-seat electoral units, each with approximately the same number of voters. Compared to the present system, it provides more geographically consistent electoral units, thus it addresses most of the most problematic issues in the current system. The main disadvantage of the proposal is that there are large differences in the number of voters between individual electoral units, which moves the system further away from the principle of equal suffrage. Another problem with the proposal is that it does not eliminate all the anomalies of the current system, which means that electoral units are not geographically consistent.

The second proposal (Figure 6 and Table 4) is based on completely different starting points. The proposal presupposes the creation of a regional level of local self-government and the harmonization of the borders of electoral units with regional borders. It builds on the proposal for the Territorial Division of Slovenia into 10 regions with special status for the City of Ljubljana and City of Maribor (Državni svet [National Council], 2019). It primarily aims to present the key advantages and disadvantages of a system based on spatially very heterogeneous electoral units. In this proposal, the spatial dimensions of electoral units are predetermined, and their size (number of seats) is determined with reference to the number of voters using a simple (Hare) quota and the largest remainder method.

Alignment of regional and electoral unit borders and the establishment of relatively small electoral units increases the geographical representativeness of the electoral system and enables closer connections between deputies and voters. Small geographically consistent electoral units eliminate the need to divide electoral units into districts, as they also ensure smaller regions are represented in the National Assembly and at the same time facilitate the smooth implementation of preferential voting, since voters get a better overview of the candidates. The biggest problem of the second proposal is that it does not meet the principle of equal suffrage. Because when there are a greater number of smaller electoral units, there are larger discrepancies in the number of voters who vote for each representative.

The third proposal (Figure 7 and Table 5) represents a kind of compromise or intermediate variant between the first and second proposals. The proposal does not specify a fixed size of electoral unit, but does set a limit on them. It envisages the creation of eight differently sized electoral units, in which a minimum of nine and a maximum 
of 12 seats are allocated. The size limit reduces the negative impact of very small/large electoral units, while increasing the flexibility to determine their spatial dimensions and the degree to which they conform to the principle of equal suffrage. At the same time, it significantly reduces the differences in how party competition plays out between individual electoral units.

Highly geographically consistent electoral units are the main advantage of the third proposal. The proposal eliminates all anomalies of the existing system and almost perfectly mirrors the established regional and sectoral divisions of the state. Another advantage of the proposal is its high degree of conformity to the principle of equal suffrage. It is also important that relatively large electoral units are less affected by changes in the spatial distribution of the population. As a result, the size of electoral units can be expected to be more stable with there being less need for redistricting. In terms of the shortcomings of the proposal, it is likely there would be differences in the nature of party competition, which are characteristic of arrangements with differently sized electoral units. It should be emphasized that differences, due to two-level allocation of seats and small differences in the size of electoral units, would not have a major impact on the division of seats between the parties, but would likely have a small impact on intra-party allocation of seats.

Any change in the organization of electoral units must include clearer criteria specifying on what basis they are formed. It is necessary to determine the permissible deviation in the number of voters between individual electoral units and to specify the criteria on the basis of which the geographical integrity of electoral units is assessed. This would avoid the different interpretations of the legislation that we are witnessing in the current debate on electoral reform. It should also be specified when or under what conditions electoral units be redrawn. Should a solution encompassing different sized electoral units be introduced then there will also need to be a clear and fair way of assigning seats among electoral units, since this would be a precondition for fair and just elections.

Reforming the organization of electoral units is not necessarily essential though it does make sense to do so, especially should preferential voting be introduced.

(Translated by James Cosier) 